\title{
Museums and Community Development: With Special Reference to Zambian Cases
}

\author{
Kenji Yoshida
}

\begin{abstract}
The museum is not only a storage place for tangible objects of the past, or a destination for tourists, it is also a base for the accumulation and dissemination of local culture, and for creating people's pride in or identity to the community. Only when people have pride in themselves and their own culture, can they challenge and overcome various difficulties. Examples of movements in Africa, especially those in Zambia where the author has been working for more than 30 years, clearly demonstrate that the museum, an institution for constructing cultures, can also be appreciated from the viewpoint of community development. The identity museums to be created should be open-minded and those that admit cultural diversity, otherwise it will result only in creating a nationalistic ideology. The networking of museums, both nationally and internationally, is thus essential.
\end{abstract}

\section{Introduction}

When we look back, controversy had been growing over ethnographic exhibitions in museums in the 1980s and 90s. Ethnographic museums throughout the world had long been focusing on cultures extraneous to the country in which the museum is located. Museums were likely to approach this task from their vantage point of their own cultures. However, in the 1980s and 1990s, people of the world who had long been the subjects of ethnographic exhibitions in large-scale museums became more aware of their own cultures and histories, and thus begun to protest against this prevalent one-sided approach to exhibitions of ethnic cultures. Under the circumstances, it became common for large-scale museums to have collaborative relationships with the people who are represented in exhibitions, in organizing exhibitions or constructing databases of their collections. Involvement of people in the activities of those large-scale museums promoted people's awareness of their own culture and history, and there is now a vigorous movement in every corner of the globe to build local or community museums to present on site the culture of the community.

\footnotetext{
K. Yoshida $(\square)$

National Museum of Ethnology, Senri Expo Park, Suita, Osaka 565-8511, Japan

e-mail: yoshidak@idc.minpaku.ac.jp
} 
While globalization has been prevailing in every aspect of human life, the significance of the museum as a device that is rooted in each local community, inherits its culture, and furthermore, newly constructs it, has been recognized more widely.

\section{Museum Training Courses}

Along with an increase in the number of museums in the world, demand for the opportunity to acquire the knowledge or techniques required for managing museums has become more vociferous year by year. However, there are only limited occasions for acquiring substantial knowledge and techniques related to museums in an integrated manner. Under such circumstances, a series of museum training courses, which has been carried out by the National Museum of Ethnology, Japan (Minpaku) in collaboration with the Lake Biwa Museum as a project sponsored by Japan International Cooperation Agency (JICA), is a very unique attempt in the world.

A total of ten trainees participate in the course every year from all over the world. As for this year's course that started on the 18th of April and finished on the 25th of July 2014, there were ten trainee participants from four countries: Jamaica, Myanmar, Egypt, and Palestinian Authority. The subjects of this 4-month course range from the history of the museum, its latest trends, methods of collection management, conservation science, exhibition design, database construction, museum education, and development of museum goods to crisis management. All of these subjects are mainly undertaken in the workshop style focusing on discussion or practice rather than giving unilateral lectures. Lecturers of this course are researchers and curators of museums in Japan such as Minpaku or the Lake Biwa Museum, and other experts are also invited according to each specialized field. We would ask a professional of an art-transporting company to give a lecture in a workshop for packing art objects, and an expert individual who is in charge of marketing for business practices. After the 2011 Tohoku Earthquake and Tsunami, training in risk management and disaster prevention has been intensified. Training trips are also on the program during the course term to visit not only museums in the Kansai area but also the museums in the Hokkaido, Tokyo, and Hiroshima areas.

There is no model that is applicable to all aspects of museum management.

It is our planned scheme that the participants search for something that is applicable to the museum activity of their own country through directly experiencing the various activities that Japanese museums provide. As far as I know, there is no such occasion on a worldwide level as this course that comprehensively serves to provide training in a wide variety of museum activities.

While the course provides them with an opportunity for training, the "trainees" are actually curators who are well experienced and have been active on the frontlines of their country's museums. Thus, in reality, this training opportunity becomes like a forum where our experiences in Japan meet their experiences, so that we are able to learn from each other and share new knowledge and recognition. 


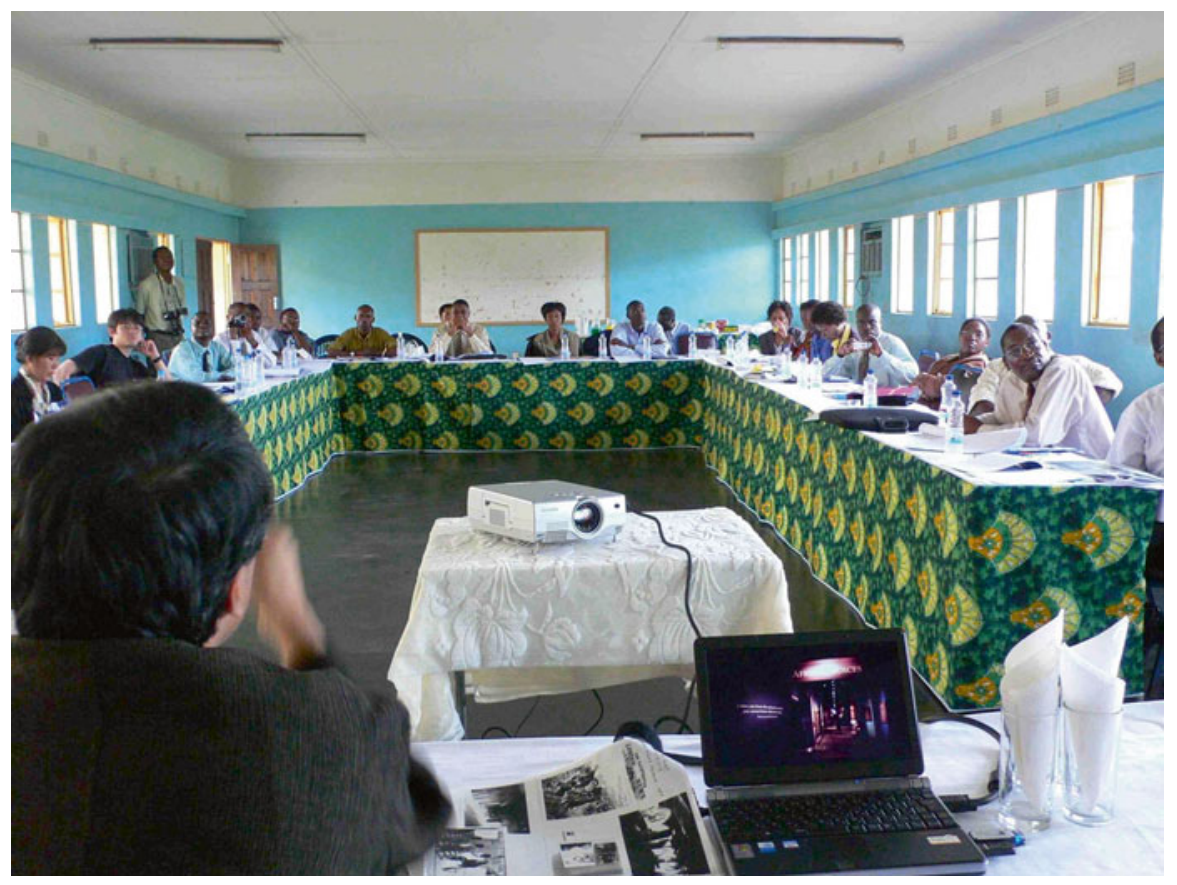

Fig. 1 Museology workshop in Livingstone 2005

We have accepted 216 trainees from 56 countries and regions in the last 21 years, considering the outcome of the current "Comprehensive Museology" course (which started in 2012 and its predecessors, i.e., the "Intensive Course on Museology" that lasted between 2004 and 2011) and the original "Museum Technology Course," which started in 1994 and lasted up to 2003. From next fiscal year 2015, we plan to renovate the course by placing more weight on the role of museums as an instrument of community development, and we will start the course under the new title of "Museums and Community Development." The global networks connecting the museums that have been constructed through these courses are a great fortune for all of the people and organizations involved in the course.

\section{Development of the Training in Japan}

But there is more than that. As for Zambia, by 2004, we had received six trainee participants in the courses. In Zambia, a workshop entitled "Museology Workshop in Livingstone 2005" (Fig. 1) was organized by the six former participants targeting museum curators of the country who did not have a chance to come to Japan for the period 4-9, December, 2005. It delighted us in that, in this way, the achievement of the training acquired in Japan can be further developed in each country and lead to unique activities of the locals. The initiative taken by the former participants in the 


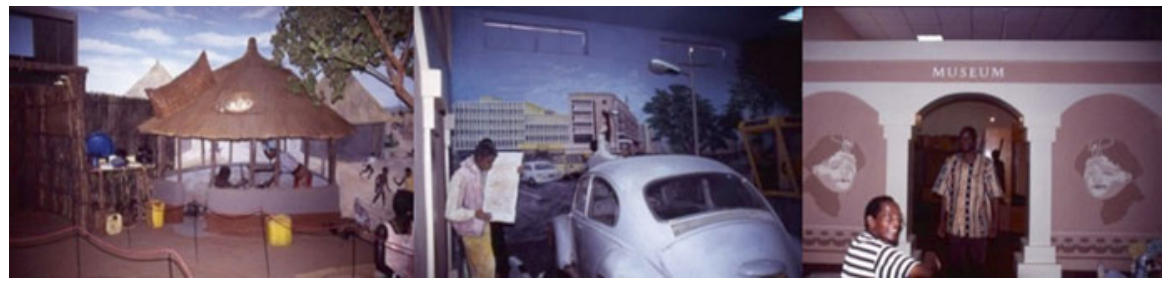

Fig. 2 New ethnographic gallery at the Livingstone Museum: village life (left), urban life (middle), and a corner called "Museum" (right)

museum training courses was highly appreciated by the JICA regional office, and from 2006 to 2008, a more intensive workshop on museum activities focusing on a particular subject each year (exhibition design in 2006, collection conservation in 2007, and documentation including the construction of a database and film making in 2008) was organized as a follow-up program to the training course. Each year, former participants in the course played the role of instructor, and we, Japanese museum specialists, also joined the workshop as facilitators. And the follow-up workshop really functions as an opportunity where a unique museology based on local specifics is jointly created by all participants. Needless to say, the current project "New Horizons in Asian Museums and Museology" which led by Professor Sonoda, has exactly the same intention and can be considered to create a unique museology in each Asian country. The form of development that we have aimed at from the very beginning of the project of the training course has finally been attained.

Visible results of the training course are now appearing in Zambia. Some temporary exhibitions on local communities at the Lusaka National Museum were installed by using the so-called carton-box technique, which was introduced during the training course in Japan. It is a form of technology that makes use of simple materials like carton boxes to make partitions and display walls for exhibitions. Achieving maximum efficiency by using minimum equipment is always a basic item on the training agenda.

The new ethnographic exhibition recently completed at the Livingstone Museum is a unique reflexive exhibition. In refurbishing the ethnographic gallery, the museum divided the gallery into three parts: Village Life, Urban Life, and a corner called "Museum" (Fig. 2). Visitors are invited to enter into the reconstruction of a village setting first, where a bicycle and plastic water tanks are placed in front of thatched huts, then to another reconstruction of urban life settings where familiar scenes in a town for visitors are reconstructed by combining paintings, photographs, and real objects, and finally to a corner called "Museum" where a typical ethnographic exhibition is developed by displaying objects visitors are actually using in their daily life. Through this exhibition, visitors are unconsciously led to review their own choice of where to live either, in a village or in town, which is a crucial question that all people in Zambia are facing, and are also invited to rethink about the nature of a museum that is showing their daily utensils. In this exhibition, visitors are not only visitors per se, but became active players in the exhibition. By being juxtaposed with reconstruction of village and urban settings, a typical ethnographic exhibition in the museum has become another reconstruction of a 
museum setting, all of which shed new light on visitors' experience either in a village, in a town, or in a museum. The curators who were engaged in realizing this exhibition said to me that they were inspired by the exhibition to which they were introduced during the course in Japan, that is "Images of Other Cultures" held at Minpaku in 1997, where the British Museum's old galleries and kiosks and roadside shops in Europe, Papua New Guinea, and Japan were reconstructed. In fact, I am the one who curated the exhibition. They say they digested some concepts of the "Images of Other Cultures" exhibition and created their new ethnographic gallery. It seems to me that this exhibition at the Livingstone Museum can be considered as a new type of reflexive exhibition that has been developed uniquely in Zambia by digesting their experience in Japan (Yoshida and John Mack 2008).

\section{Creation of Festivals and Local Museums}

Perhaps there is a particular reason that Zambian museums, or more precisely Zambian museum professionals, are now so acquisitive of knowledge and techniques in museology. It is not because of my involvement.

In Zambia, there have been few festivals organized based on a whole ethnic group. One of the few examples of this sort is kuomboka, or Royal Barge Festival, of the Lodzi people. Having been inspired by such a big-scale festival, in 1980, a ceremony called nchwala where the first harvest of the year is brought to the King was revived among the Ngoni people (Fig. 3). Following the Ngoni, a neighboring

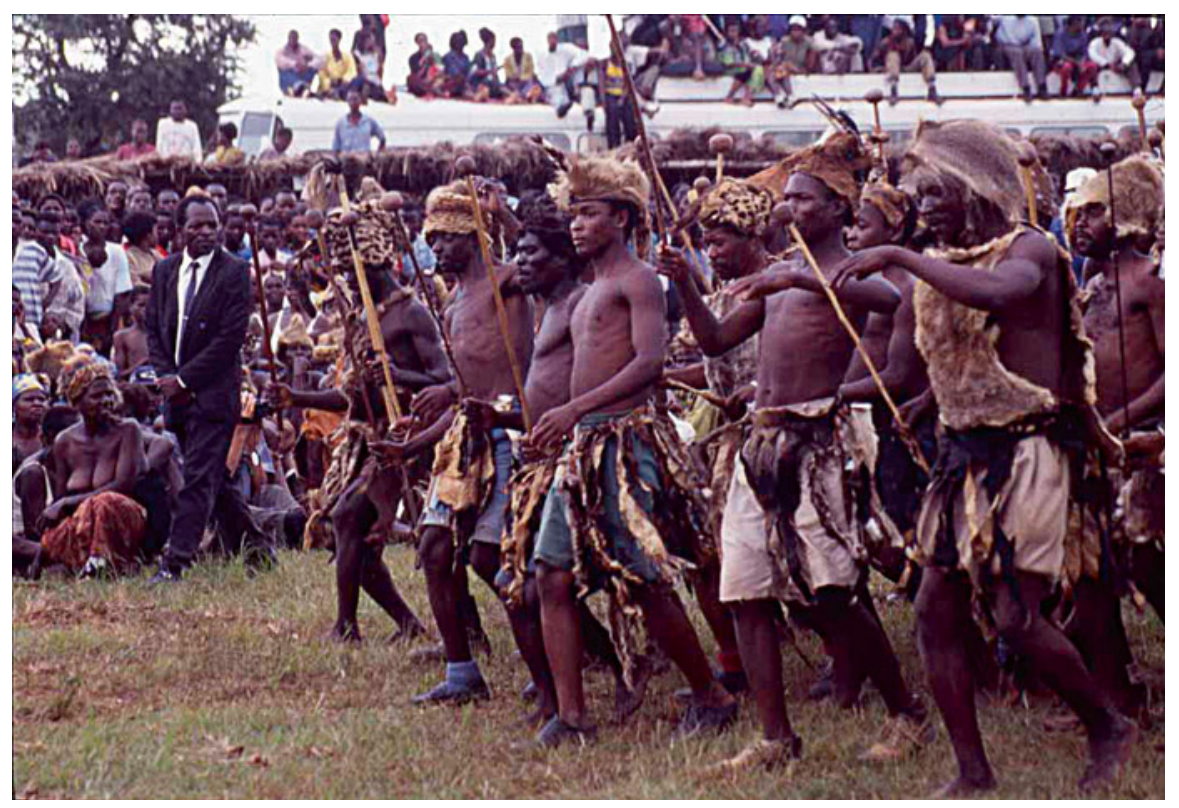

Fig. 3 Nchwala ceremony of Ngoni people. 1999 


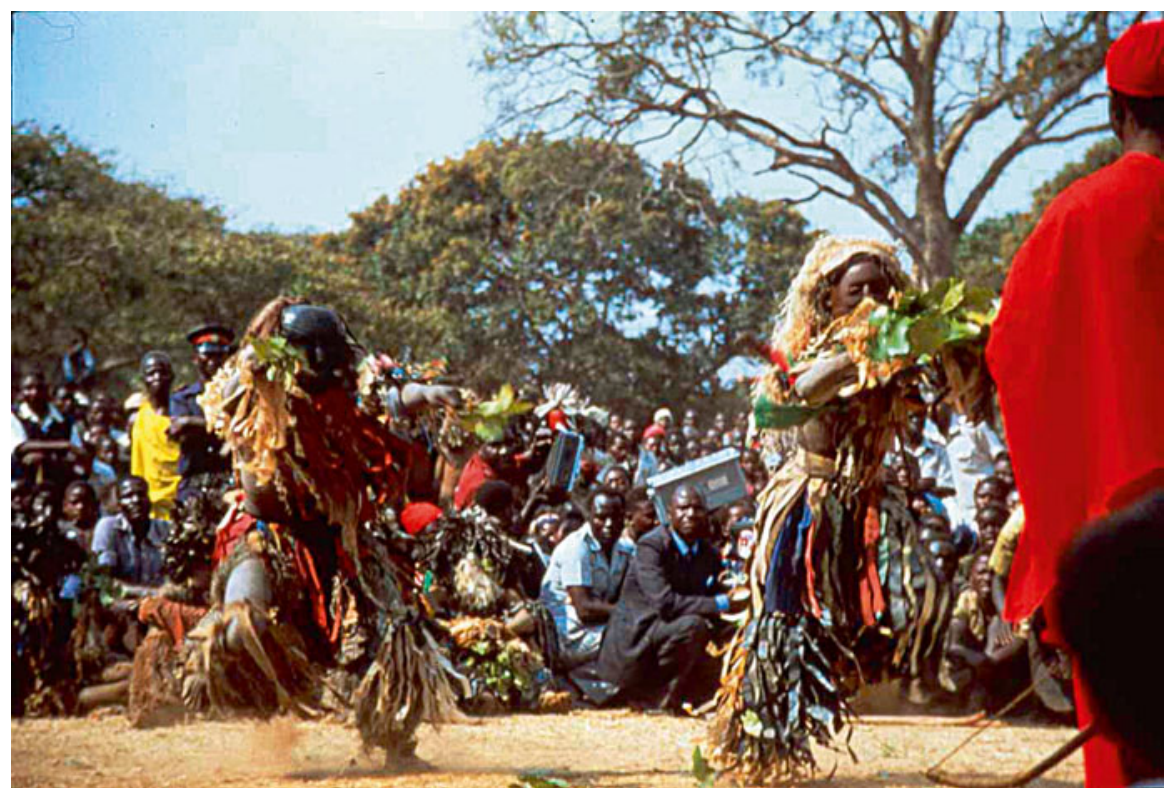

Fig. 4 Kulamba ceremony of Chewa people. 1984

ethnic group named Chewa created a harvest festival called kulamba in 1984, based on an old custom of annual tribute to their King (Fig. 4). Stimulated by these movements, yet another ethnic group in the region, the Nsenga, invented a rain-calling ceremony called twimba in 1988, by combining various old customs (Fig. 5). It is noteworthy that the purposes and dates of the ceremonies are well differentiated so that they do not overlap each other. The Nchwala of the Ngoni is to celebrate the first harvest of the year, and is thus held in the midst of the rainy season. The Chewa's kulamba is a harvest festival, and is held in the depths of the dry season. The twimba of the Nsenga is a rain-calling ceremony, and is held at the beginning of the rainy season. Since then, the movement of creating ethnic festivals is spreading over the whole country under similar slogans like "Let's start our tradition," and now almost all major ethnic groups, which number 73, have got their own annual festivals. Why are they differentiated in date and meaning? Some chiefs and kings explained by saying unanimously, "Otherwise, our own ceremony would not be well covered on TV, and we would also lose an important occasion for lodging appeals to the President and his ministers." The central government actually supports these movements by providing transport for audiences, and by sending representatives like ministers and in some cases the President himself to each festival.

In retrospect, there are not many options for various ethnic groups to proclaim their identity by means of festivals while getting along in harmony with others than to "revive" each ethnic group's festival in a short period. It was indeed a way of avoiding particular groups becoming prominent in society. 


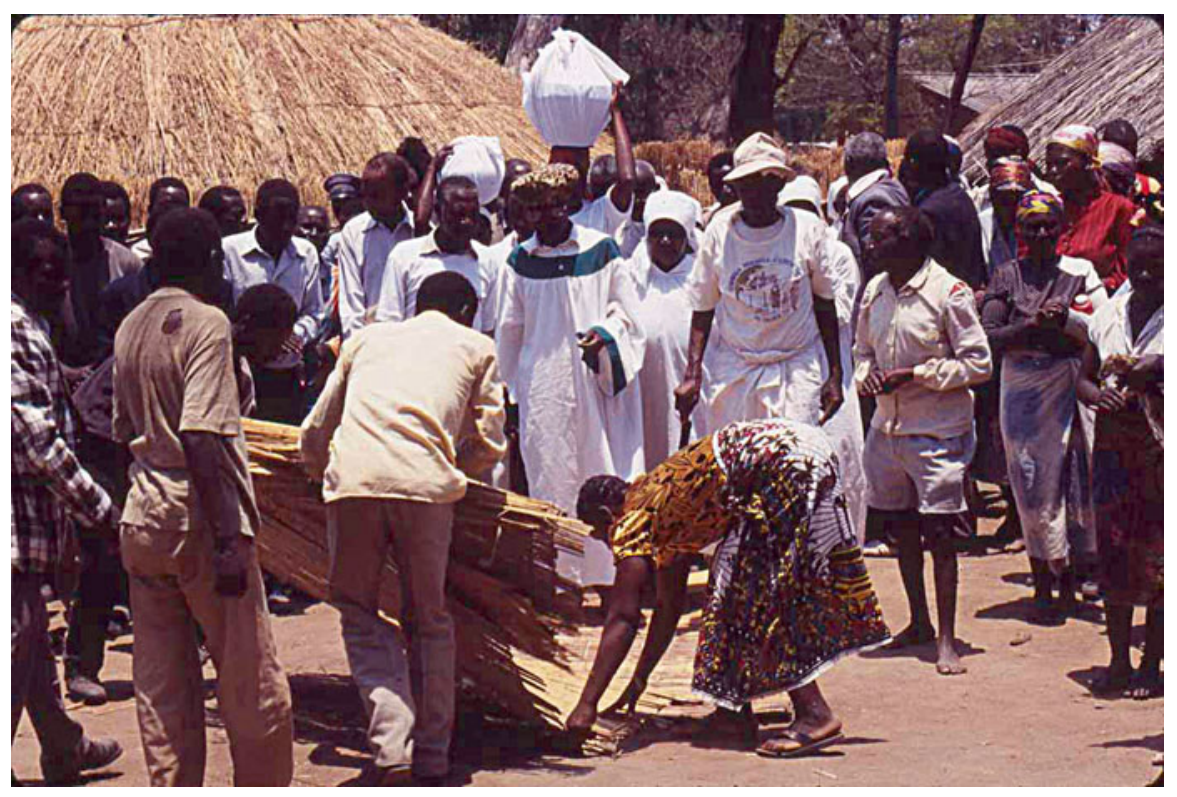

Fig. 5 Twimba ceremony of Nsenga people. 1999

In the 1990s, having created festivals, each group started planning to build its own museum to show its cultural heritage. Some have already been established, most of which are located at the very sites of the annual festivals. The Nayuma Museum built by the Lodzi people in 1986 is a pioneering museum in the trend (Fig. 6). The Choma Museum in Choma in the Southern Province, which is dedicated to the Tonga community, can also be mentioned in this context (Fig. 7).

Another example is the Moto Moto Museum, which was originally established by a Catholic Father, Jean Jacques Corbeil. He built an ethnographic collection that includes objects used in girls' initiation ceremony called chisuingu while he was working in Bemba land (Corbeil 1982). The collection was donated to the national government and the museum became one of the national museums in 1974. But because of the character of its collection, the museum is nowadays playing the role of a community museum for the Bemba people (Figs. 8 and 9).

Yet many other museums are now under construction or contemplation. Among them is a museum called Nsingo Hall in Ngoni land. The Ngoni people are now trying to convert the former municipal hall into their own community museum.

As for the Chewa people, with whom I have been carrying my fieldwork for more than 30 years, their masked dance called gule wamukulu (Fig. 10), together with another masked dance in Zambia, that is, the makishi dance of the Luvale people (Fig. 11), was registered in 2005 as Intangible Cultural Heritage by UNESCO. After the registration, the Chewa people, or more precisely, the Chewa Traditional Council 


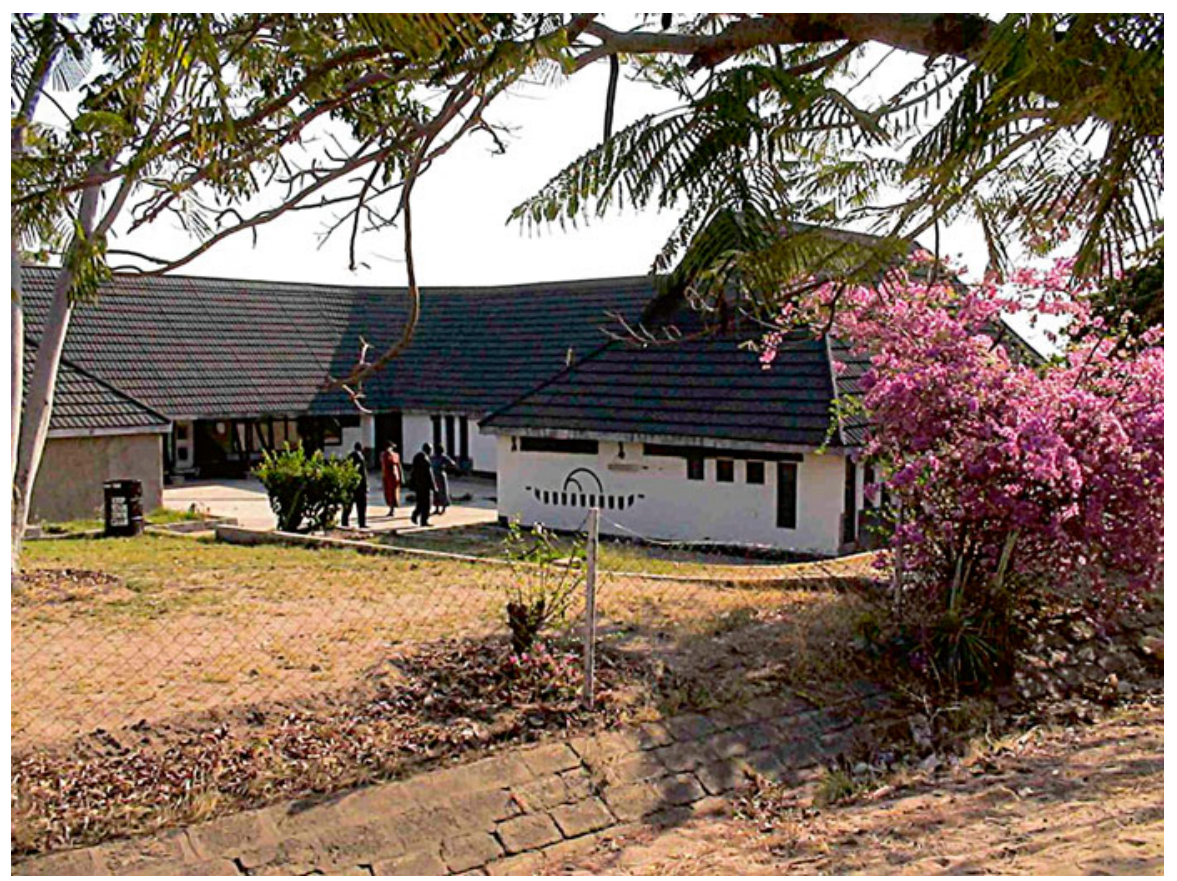

Fig. 6 Nayuma Museum in Mongu

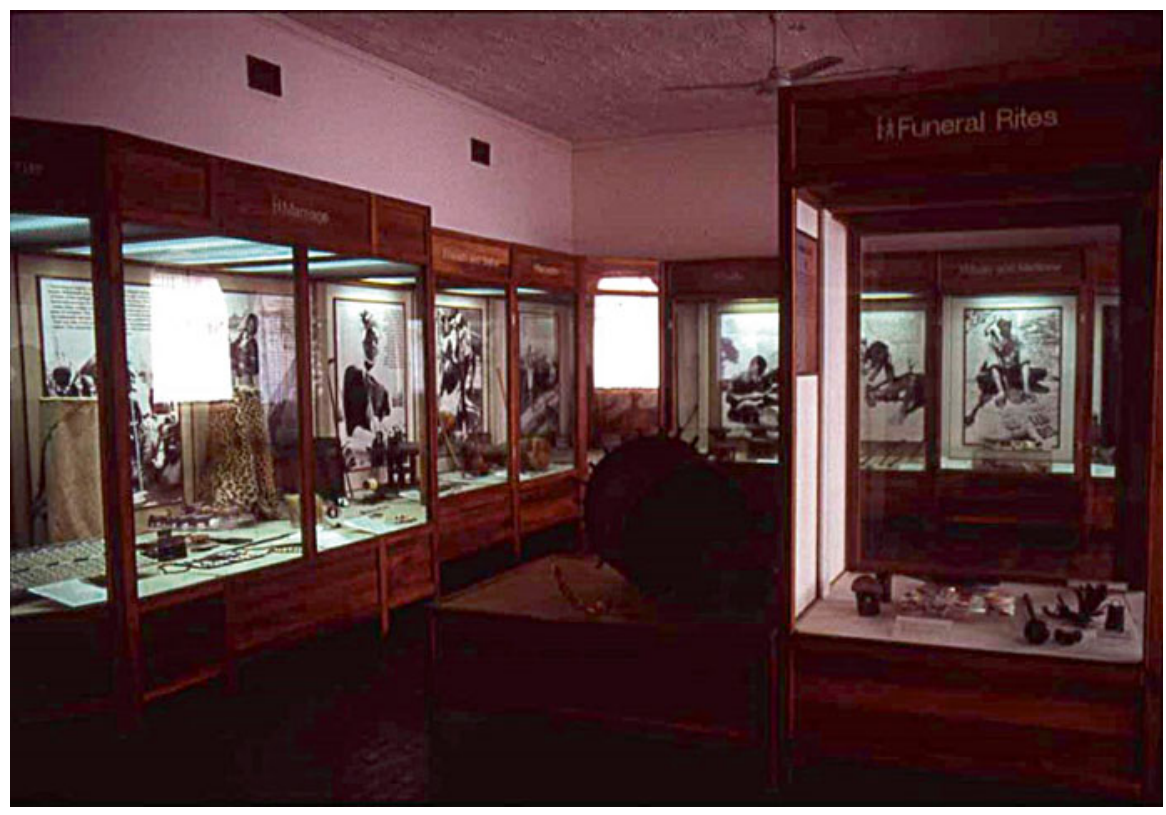

Fig. 7 Choma Museum in Choma 


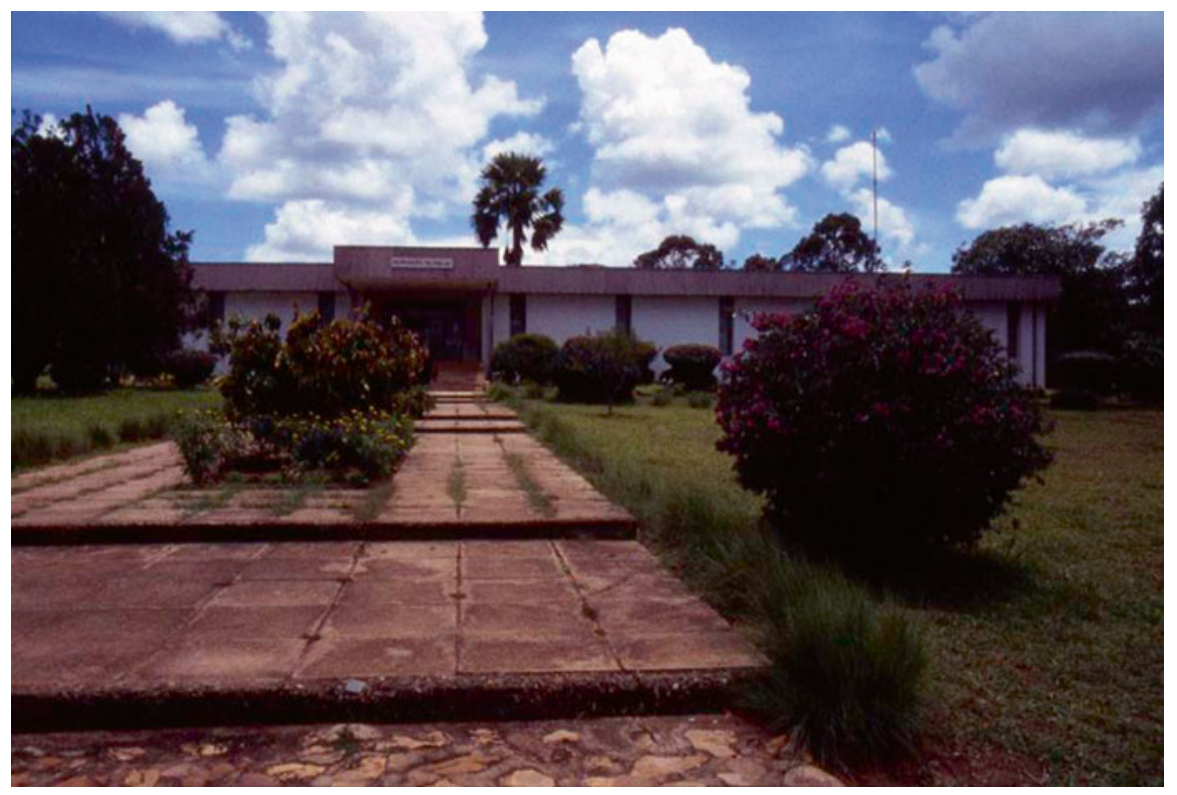

Fig. 8 Moto Moto Museum in Mbala

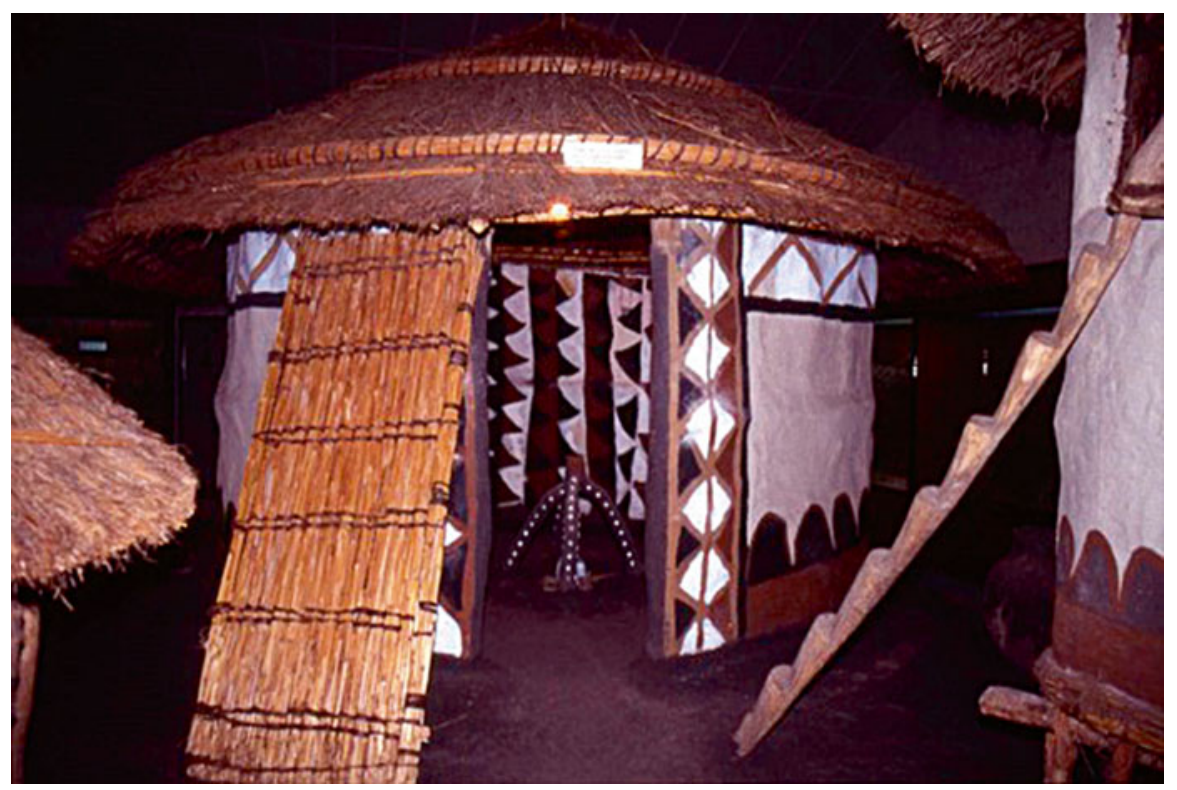

Fig. 9 Reconstructed chisuingu girls' initiation hut in the Moto Moto Museum 


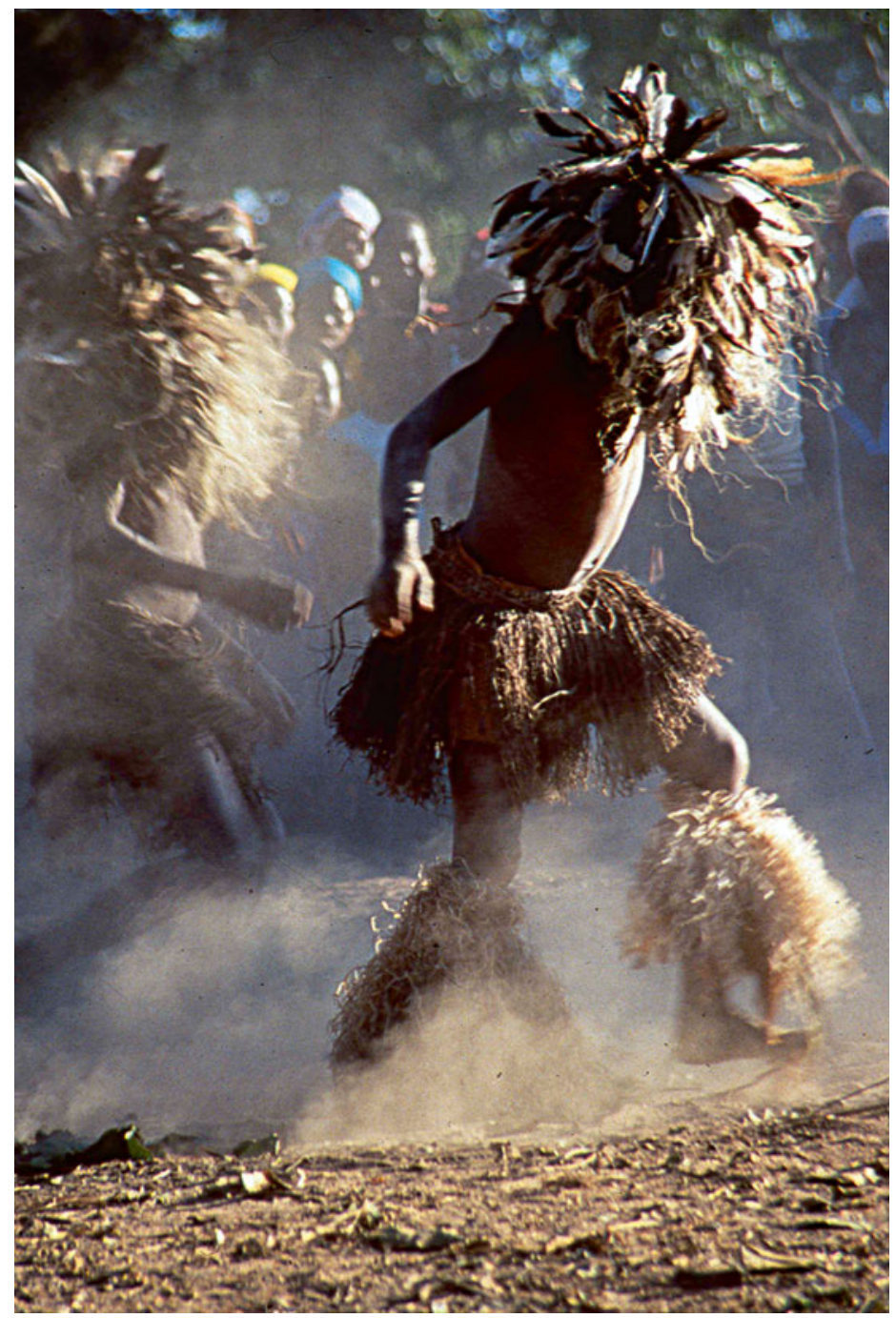

Fig. 10 Gule wamukulu dance of Chewa people

that was established at the time of the first kulamba ceremony in 1984 decided to create a museum at the site of the kulamba ceremony. Though the building is not yet completed, the plan is well underway. A similar movement is also going along among the Luvale people. When I started my fieldwork among the Chewa, it was scarcely known that the Chewa people has a masked-dance tradition (Yoshida 1993). When I think of those days, I feel I am living in a completely different age.

It is noteworthy that the target visitors of these museums are people of the local communities rather than tourists, and that the museums seek to strengthen people's 


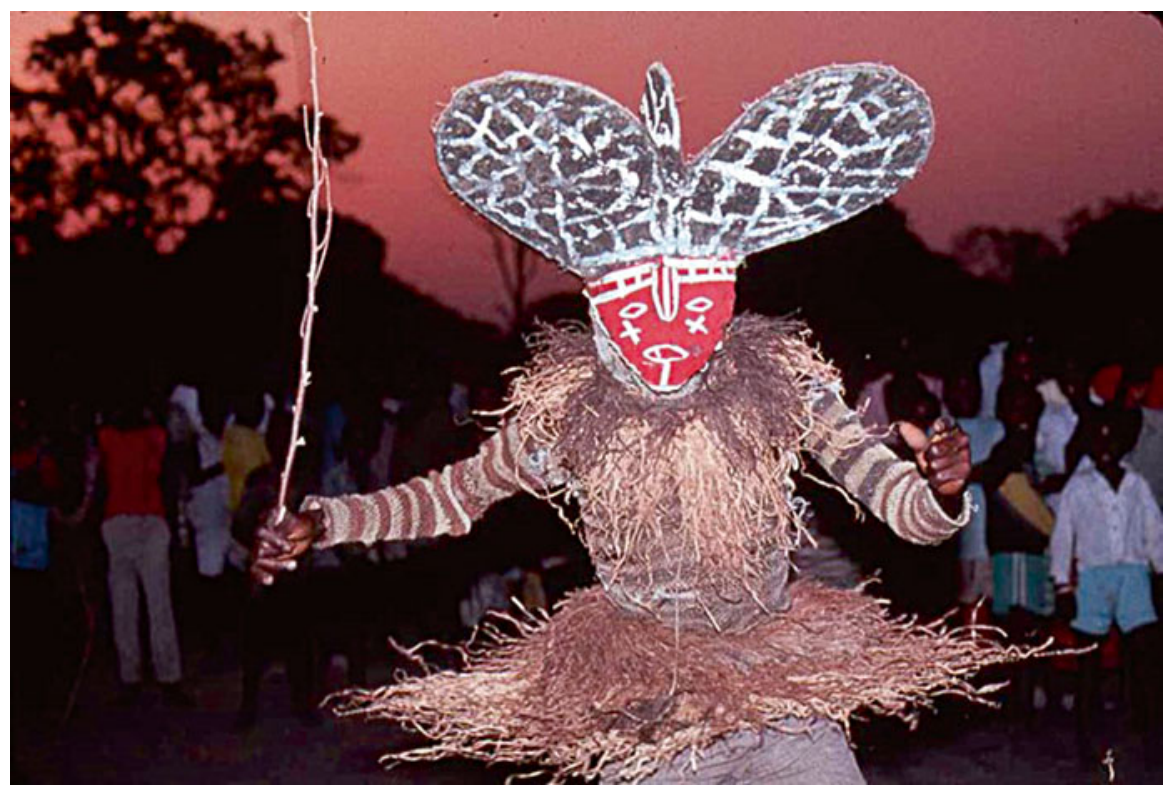

Fig. 11 Makishi dance of Luvale people

pride in their culture and to transmit their traditional culture to a younger generation. The notion of the museum is, however, quite new to the most of the local people. People are finding their own way of creating their museums.

Out of these endeavors, some notable activities are also emerging. Moto Moto Museum, which I introduced above as a community museum for the Bemba people, launched an outreach project to prevent HIV infection in their surrounding areas. Some pieces in their collection, which were used for traditional education during girls initiation ceremony called chisungu, were displayed and used for providing villagers, especially women, with information about prevention of HIV infection.

Another museum, the Livingstone Museum (Fig. 12), which again I referred to above, held an exhibition entitled "What we have been told about Independence" (Fig. 13), which was brought to fruition by collecting reports written by school children of what they had been told by their parents and grandparents about Independence. This exhibition gave people of the local community an opportunity to re-discover their historical heritage, and led to the development of some touristic spots.

In these ways, the museum is now playing the role of instrument for the development of communities. The museum, an institute of constructing cultures, can also be appreciated from the viewpoint of community development. 


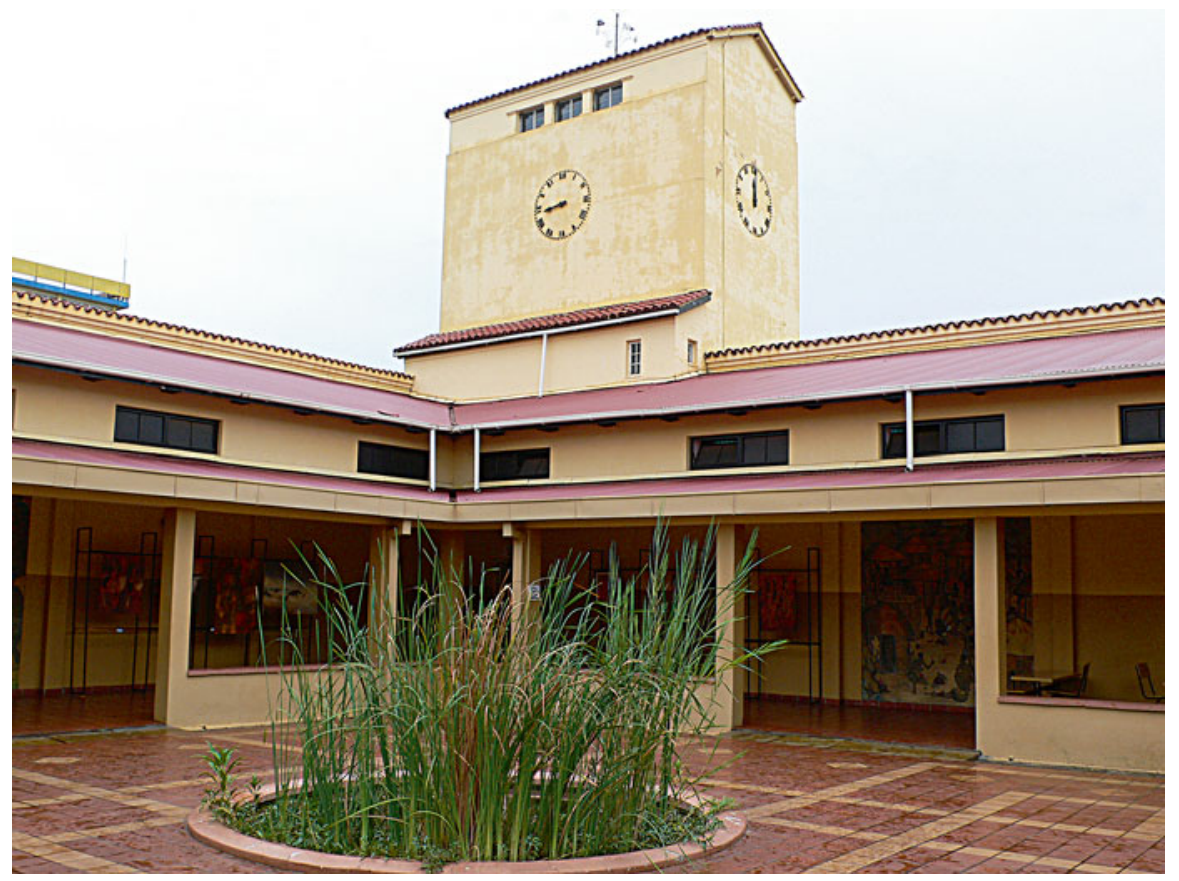

Fig. 12 Livingstone Museum in Livingstone

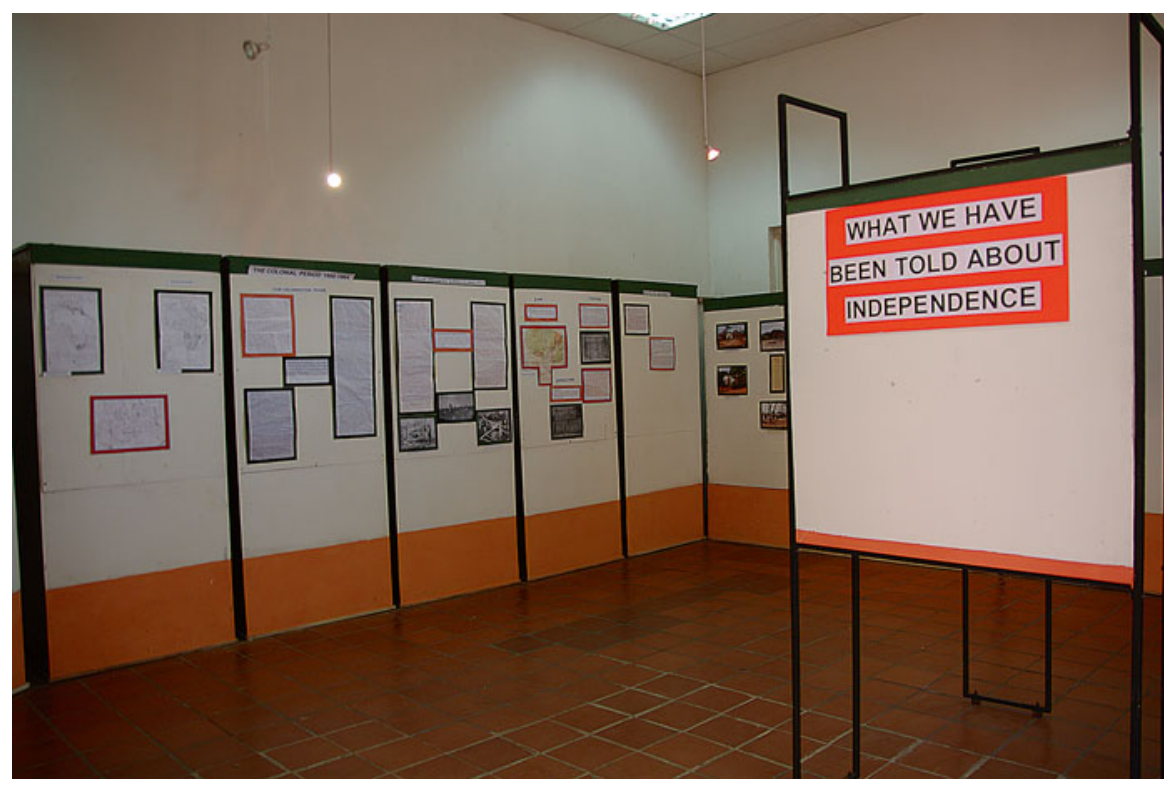

Fig. 13 "What we have been told about Independence" Exhibition at the Livingstone Museum 


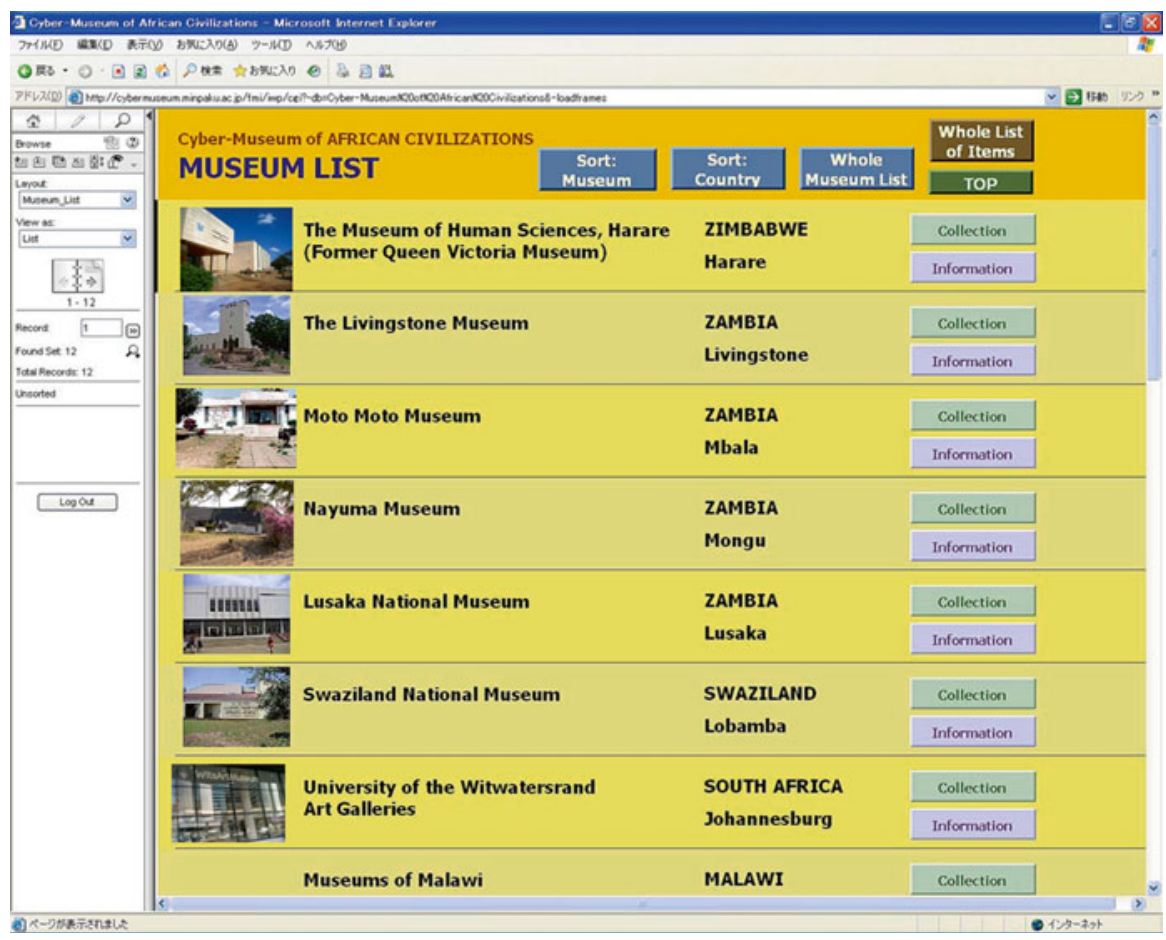

Fig. 14 Cyber-Museum of African Civilizations

\section{Conclusion}

Before concluding, it should be noted here that, if the identity created or strengthened by this movement is narrow-minded, it will result only in creating a nationalistic ideology. The identity museums to be created should be open-minded and those that admit cultural diversity. For this purpose, the networking of museums, both nationally and internationally, is essential.

In Zambia, the National Museums Board based in the capital city Lusaka is supporting the movement of establishing local museums on the one hand, and it is trying to network these movements on the other. I myself am also supporting their activities by connecting the network with the various programs carried out by our museum, the National Museum of Ethnology, Japan.

In this paper, I have introduced a series of museological workshops held in Zambia as follow-up programs to the training course in Japan. To these workshops, people who are involved in constructing community-based museums are also invited for the purpose of sharing knowledge and experience in the field of museology. A database sharing information on the collections of participating museums is also constructed (Fig. 14). Although there are many ethnic groups in Zambia, almost all of them belong to the so-called Bantu-speaking language group, and they share 
many aspects of materials culture. The database can demonstrate the existence of this commonality that crosses national borders. Construction of the database is also a part of our endeavor to foster an open-minded identity. The role of a museum as an instrument for constructing culture and society that is rooted in the relevant community and yet equipped with a sense of open-minded identity will certainly become increasingly vital in the coming age.

The museum has long been considered as a place of representation, preservation, and conservation of the tangible cultural properties of the past. From this viewpoint, there seems little room for museums to contribute to community development. However, the museum is not only a storage of tangible objects of the past, nor just a tourist spot, but a base of accumulation and dissemination of local culture, including knowledge, memory and technology that has been transmitted from one generation to another in the community, and thus, a base for creating people's pride in or identity to the community. Only when people have pride in themselves and their own culture can people challenge and overcome various difficulties. In this sense, museums may well be considered to be a fundamental instrument of community development, and thus development aid.

Open Access This chapter is distributed under the terms of the Creative Commons AttributionNonCommercial 4.0 International License (http://creativecommons.org/licenses/by-nc/4.0/), which permits any noncommercial use, duplication, adaptation, distribution and reproduction in any medium or format, as long as you give appropriate credit to the original author(s) and the source, provide a link to the Creative Commons license and indicate if changes were made.

The images or other third party material in this chapter are included in the work's Creative Commons license, unless indicated otherwise in the credit line; if such material is not included in the work's Creative Commons license and the respective action is not permitted by statutory regulation, users will need to obtain permission from the license holder to duplicate, adapt or reproduce the material.

\section{References}

Corbeil, J.J. 1982. Mbusa: Sacred Emblems of the Bemba. Mbala, Zambia: Moto Moto Museum. Yoshida, Kenji. 1993. Masks and Secrecy among the Chewa. African Arts 24(2): 34-45. 92.

Yoshida, Kenji and John Mack eds. 2008. Preserving the cultural heritage of Africa: Crisis or renaissance? Oxford: James Currey. 